\title{
KONSEP KESEDERHANAAN TARI RENTENG DI DESA SAREN NUSA PENIDA, KLUNGKUNG, BALI
}

\author{
Anak Agung Gde Agung Indrawan \\ Program Pascasarjana \\ Institut Seni Indonesia Denpasar \\ Jl. Nusa Indah, Sumerta, Denpasar, Bali 80235 \\ Email: agungindrawan88@gmail.com
}

\begin{abstract}
ABSTRAK
Tari Renteng merupakan tarian kelompok yang disakralkan dan hanya ditarikan oleh para wanita dewasa di Desa Saren, Nusa Penida, Klungkung, Bali. Gerakan tarian ini bersifat mengalun dan berulang-ulang, serta penyajian, busana, dan iringan musiknya sangat sederhana. Kesederhanaan pada bentuk dan penyajian tari Renteng menimbulkan keindahan yang memberikan pengalaman estetis formalistis dari tarian ini. Akan tetapi, bentuk pengalaman estetis formalistis belum banyak masyarakat memahaminya. Fokus permasalahan dalam kajian ini adalah bagaimana konsep kesederhanaan pada tari Renteng di Desa Saren. Penelitian ini membahas tentang konsep bentuk kesederhanaan pada tari Renteng yang dapat menimbulkan pengalaman estetis formalistis. Tujuan penelitian ini untuk mendapatkan gambaran secara konseptual wujud dari tarian ini berdasarkan pada kesederhanaan bentuknya. Jenis penelitian ini adalah deskriptif analitik dengan menggunakan metode observasi nonpartisipan, wawancara dan dokumentasi. Hasil penelitian ini, bahwa konsep kesederhanaan pada tari Renteng terdiri dari kesederhanaan unsur, kesederhanaan struktur, dan kesederhanaan teknik. Kesimpulannya adalah pertama, konsep kesederhanaan unsur atau elemen pada tari Renteng merupakan kesederhanaan komposisi dari unsur-unsur yang terdapat pada tarian ini, yang meliputi gerak, desain lantai dan desain atas, busana, serta iringan musik; kedua, konsep kesederhanaan struktur tari Renteng merupakan rancangan yang penerapannya tersusun melalui gerak sederhana dan pola yang bersifat repetitif; Ketiga, konsep kesederhanaan teknik tari Renteng tercapai melalui cara yang sederhana dengan kompleksitas rendah atau tidak rumit sehingga mudah untuk ditarikan.
\end{abstract}

Kata kunci: konsep, bentuk, tari sederhana, Renteng.

\begin{abstract}
Renteng Dance is a group dance that is sacred and only danced by adult women in Saren Village, Nusa Penida, Klungkung, Bali. The dance movements are flowing and repetitive, and the presentation, fashion and the music accompaniment is very simple. The simplicity in the form and presentation of the Renteng dance gives rise to beauty that gives a formalistic aesthetic experience. However, the form of formalistic aesthetic experience has not been understood by many people. The focus of the problem in this study is how the concept of simplicity in the Renteng dance in Saren Village. This study discusses the concept of a simplicity form in the Renteng dance that can lead to formalistic aesthetic experience. The purpose of this study is to get a conceptual description of the dance form based on the simplicity of its form. This research is analytic descriptive using non-participant observation methods, interviews and documentation. The results of this study show that the concept of simplicity in Renteng dance consists of simplicity of elements, simplicity of structure, and simplicity of technique. The conclusion includes first, the concept of simplicity of elements in Renteng dance is the simplicity of the composition of the elements contained in this dance, which includes motion, floor and upper designs, clothing, and musical accompaniment; second, the concept of the simplicity of the Renteng dance structure is a design whose application is composed through the simple movements and repetitive patterns; Third, concept of the simplicity of Renteng dance technique is achieved through the simple methods with low or uncomplicated complexity so that it is easy to dance.
\end{abstract}

Keywords: concept, form, simple dance, Renteng. 


\section{GELAR Jurnal Seni Budaya}

\section{A. Pengantar}

Tari sebagai sarana ritual sering dijumpai di berbagai daerah bahkan di Bali sendiri. Pada umumnya tari ritual dimiliki oleh sekelompok masyarakat atau bersifat komunal dan disakralkan. Bentuk tari ritual sangat sederhana, ditarikan secara berkelompok atau massal dengan gerakan yang sederhana bahkan busana dan iringan musiknya pun sangat sederhana. Tari ritual dapat dikategorikan sebagai tarian primitif, jenis tarian dengan bentuk gerak sederhana yang sering dihubungkan dengan kekuatan alam, supranatural, maupun pemujaan atau komunikasi dengan dewa-dewa, serta ritual penyembahan kepada roh nenek moyang (Hadi 2007).

Terkait dengan tari ritual, salah satu wilayah di Bali yang memiliki tarian ritual adalah Desa Saren, Kecamatan Nusa Penida, Kabupaten Klungkung, Provinsi Bali. Tari ritual di Desa Saren merupakan tarian primitif yang difungsikan sebagai saran ritual dalam upacara keagamaan dan sebagai sarana persembahan berhubungan dengan hasil sumber daya alam masyarakat Desa Saren. Tari Renteng ditarikan secara berkelompok oleh para wanita dewasa atau orang tua dengan jumlah penari ganjil. Gerak tarinya sangat sederhana, busana dan iringan musiknya juga sangat sederhana. Berdasarkan bentuknya tersebut, tarian ini dapat dikategorikan sebagai tarian sederhana, yaitu sebuah tarian yang belum ditata secara koreografis. Soedarsono mengatakan bahwa tarian sederhana memiliki bentuk gerak yang belum begitu digarap secara koreografis. Gerakannya sederhana, iringan musik juga sederhana, serta pakaian dan riasannya pun sangat sederhana (Soedarsono 1981).

Renteng, berdasarkan Kamus Jawa Kawi-Indonesia berarti dalam untaian atau dalam deretan (Maharsi 2009). Berdasarkan sumber kamus tersebut, Renteng dapat diartikan sebagai sebuah tarian yang dilakukan secara beruntai atau berderet. Namun, menurut Ida Ayu Made Diastini dalam makalah seminarnya yang berjudul "Viralnya Tari Rejang Renteng", mengatakan bahwa Renteng berasal dari kata renta atau tua. Dalam artian luas bukan tua tubuh, akan tetapi orang sudah dituakan atau sudah menikah (Diastini, 2018). Merujuk pada kedua sumber tersebut, tari Renteng dapat diartikan sebagai tarian yang dilakukan oleh penari yang sudah menikah dan dituakan serta ditarikan secara beruntaian atau berderet. Secara etimologis kedua sumber diatas tentunya memiliki pengertian yang berbeda. Jika dilihat dari bentuknya, secara harafiah kedua sumber tersebut memiliki pembenaran masing-masing.
Sebagai penelitian awal, Tari Renteng menarik untuk dikaji, karena memiliki bentuk yang sederhana. Berdasarkan hal tersebut, semangat masyarakat Desa Saren dalam melestarikan tari Renteng ini, untuk menghilangkan rasa "malu" yang pada awalnya melekat di benak mereka, tentang wujud dari tarian ini. Sebagai sebuah kesenian yang mencirikan kearifan lokal, tari Renteng dapat memberikan pengamalan estetis bagi yang menonton melalui kesederhanaannya. Tari Renteng memberikan pengalaman estetis bagi subjek berupa emosi estetis formalistis yang di dalamnya terdapat rasa tenang dan senang, kesan sederhana dan keseimbangan yang ditimbulkan oleh bentuk dan struktur tari Renteng (Indrawan 2019). Akan tetapi, masyarakat baik di Nusa Penida maupun masyarakat luar belum merasakan dan memahami keindahan formalistis pada tarian ini. Permasalahan dalam kajian ini adalah bagaimana konsep kesederhanaan pada tari Renteng di Desa Saren, Nusa Penida, Klungkung, Bali.

Kajian ini terfokus pada konsep yang menjadi landasan, sesuatu hal yang dapat menjadi acuan keberadaan tari Renteng sebagai sebuah tarian yang bersifat sakral dan menjadi simbol representasi masyarakat Desa Saren. Kajian atau penelitian ini membahas tentang kesederhanaan yang terdapat pada tari Renteng di Desa Saren, Nusa Penida, Klungkung, Bali sebagai sebuah konsep yang melatarbelakangi wujud holistik tarian ini. Analisis dilakukan pada konsep kesederhanaan unsur, struktur, dan teknik. Jenis penelitian ini adalah deskriptif analitik dengan menggunakan metode observasi non partisipan dan dokumentasi. Analisis terfokuskan pada bentuk dan pementasan tari Renteng. Penelitian ini merupakan bagian terkecil dari tesis yang peneliti tulis. Tujuannya adalah untuk mendapatkan gambaran secara konseptual wujud dari tarian ini berdasarkan pada kesederhanaan bentuknya.

\section{B. Pembahasan}

\section{Bentuk}

Pengertian bentuk sangatlah luas, seperti gambaran, rupa, wujud, susunan, dan lain sebagainya. Suzanne K. Langer dalam bukunya yang berjudul Problematika Seni memberikan sebuah gambaran arti dari bentuk dalam perspektif seni. Pengertian bentuk mengarah pada sesuatu yang lebih abstrak; bentuk pengertian yang paling abstrak berarti struktur, artikulasi, hasil menyeluruh dari hubungan berbagai faktor yang saling bergayutan, atau lebih tepatnya cara dirakitnya keseluruhan aspek. Pengertian abstrak 
terkadang disebut "bentuk logis" melibatkan ekspresi. Cara yang paling mudah untuk memegang cita "bentuk logis" adalah dengan menelusuri asalmuasalnya(Langer 2006). Bentuk secara abstaksi sebagai katagorisasi dari susunan yang saling terkait atau berhubungan. Selanjutnya, untuk dapat melihat atau memahami susunan tersebut, perlu adanya penelusuran elemen-elemen pembentuknya secara mendalam melalui sebuah analisis. Jika dikaitkan dengan seni tari, bentuk dalam tari adalah susunan elemen-elemen tari yang saling terkait antara satu dengan yang lain, sehingga memberikan gambaran atau wujud dari tarian tersebut. Wujud dari karya seni terdiri dari beberapa unsur yang saling terkait, tidak dapat dipisahkan yang pada akhirnya terwujud menjadi satu kesatuan (Suandewi 2016). Elemen-elemen tersebut dalam seni tari dapat berupa gerak sebagai unsur utama, iringan musik, penari, tata rias dan busana, tempat pementasan, maupun struktur pementasan.

\section{Konsep Kesederhanaan}

Konsep, secara harfiah adalah rancangan, ide atau pengertian yang diabstrakkan dari peristiwa kongkret, atau gambaran mental dari objek, proses, atau apa pun yang ada di luar bahasa yang digunakan oleh akal budi untuk memahami hal-hal lain. Konsep dapat diartikan sebagai abstraksi mengenai suatu fenomena yang dirumuskan atas dasar generalisasi sejumlah karakteristik kejadian, kelompok, ataupun individu tertentu (Rihandiyo 2010). Dapat juga diartikan sebagai suatu representasi abstrak serta umum mengenai sesuatu yang bertujuan menjelaskan suatu benda, gagasan, atau peristiwa (Ibeng 2019). Berdasarkan pendapat di atas, konsep merupakan suatu rancangan, ide, atau gambaran yang bersifat abstrak berkaitan dengan entitas dari sebuah objek.

Kesederhanaan merupakan kata sifat yang berasal dari sederhana, yaitu sesuatu yang bersahaja, tidak berlebihan, tidak banyak seluk-beluk atau kesulitan, dan lain sebagainya. Sederhana dapat dipadankan dengan istilah simpel, yaitu mudah dikerjakan, dapat dimengerti, atau tidak berbelit-belit. Simple berarti mudah dipahami dan dilaksanakan, tidak rumit, terdiri dari satu elemen pengoperasian (Elkin 2004). Dengan kata lain kesederhanaan adalah suatu tindakan yang dapat dilakukan atau dioperasikan serta dimengerti melalui satu elemen. Kesederhanaan dalam seni tari berarti bahwa tari sangat efektif melalui pembatasan diri pada yang esensiil (Hawkins 2003).

Pernyataan Hawkins tersebut dapat dikatakan sebagai sebuah konsep dalam mewujudkan karya seni yang mengacu pada esensinya, dalam hal ini adalah seni tari. Keefektifan atau kesederhanaan sebuah tarian tercapai jika diatur berdasarkan kedalaman esensinya. Atau dengan kata lain melalui pengaturan unsur dasar, kesederhanaan struktur, dan teknik dapat menjadikan tarian tersebut bersifat efektif. Mengambil dari pemikiran Dharsono, kesederhanaan dalam desain pada dasarnya adalah kesederhanaan selektif dan kecermatan pengelompokan unsur-unsur artistik dalam desain, yang di dalamnya mencakup beberapa aspek yaitu kesederhanaan unsur, kesederhanaan struktur, dan kesederhanaan teknik (Dharsono 2017).

Dapat dikatakan bahwa, kesederhanaan dalam tari diartikan sebagai suatu tarian yang dapat dilakukan atau ditarikan serta dapat dipahami melalui komposisi yang sederhana. Pengertian tersebut dapat dikatakan sebagai sebuah konsep pada jenis tarian sederhana seperti tari Renteng di Desa Saren.

\section{Kesederhanaan Unsur}

Unsur atau elemen yang terdapat pada tari Renteng tidak serumit tarian ritual lainnya yang memiliki pola gerak yang kompleks, desain lantai yang artistik, dan tata rias serta busana yang mencolok atau glamour. Tari Renteng merupakan tarian yang dapat digolongkan ke dalam jenis tarian sederhana, karena dilihat dari unsur atau elemen-elemen yang terdapat pada tarian ini meliputi gerak, desain, busana, dan iringan musiknya terbentuk atau dibuat sangat sederhana. Gerak merupakan unsur utama dan baku dalam pertunjukan tari, yang dihasilkan melalui tubuh penari. Melalui gerak, penari dapat memvisualisasikan tari tersebut. Tari adalah ekspresi yang menggunakan bahasa nonverbal. Gerak tubuh adalah bahasanya. Oleh sebab itu, gerak dipandang sebagai substansi utama (I Wayan Dibia, FX. Widaryanto 2006). Secara keseluruhan hal tersebut adalah sebuah rancangan entitas komposisi dari unsur atau lemen-elemen yang terdapat pada tari Renteng. Dengan kata lain, keseluruhan komposisi pada tari Renteng merupakan sebuah wujud yang terkonsep melalui kesederhanaan unsur atau elemen yang meliputi gerak, desain, busana, dan iringan musik.

Gerak tari Renteng sendiri terdiri dari tiga jenis gerakan antara lain pertama, ngelikas yaitu gerakan berjalan yang menekankan pada langkah kaki menyilang. Pada tari Renteng, gerakan ngelikas dilakukan dengan berjalan menyilang ke depan. Posisi badan penari ngaed atau mendak menghadap ke samping kanan dan dicondongkan, wajah penari Renteng menghadap ke sudut kiri dengan mata nyerere ke depan. Posisi tangan kiri lurus kesamping 


\section{GELAR Jurnal Seni Budaya}

kiri dan tangan kanan ditekuk atau ngagem. Kedua tangan bergerak naik dan turun serta kepala meliukliuk mengikuti langkah kaki dan tangan.Contoh gerak ngelikas dapat dilihat pada gambar 1. Secara spesifik ngelikas merupakan tandang, gerakan berjalan atau berpindah dari suatu gerakan pokok ke gerakan pokok yang lain (Djayus 1980). Ngelikas dapat diartikan sebagai gerakan berjalan lambat ke depan, dengan menyilangkan kaki secara bergantian. Badan dicondongkan ke depan, kepala diliukkan mengikuti langkah kaki sedangkan wajah menghadap ke sudut kiri dan mata nyerere ke depan (Penyusun 2000).

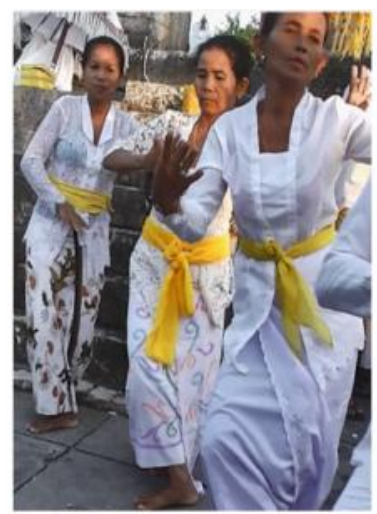

Gambar 1.

Gerakan Ngelikas pada tari Renteng

Kedua, ngoyod yaitu gerakan menggoyangkan badan ke kanan dan ke kiri dengan dinamika yang lambat maupun cepat. Pada tari Renteng gerakan ngoyod dilakukan dengan dinamika yang lambat namun mengalun mengikuti irama gamelan. Gerakan ngoyod dapat dilihat pada gambar 2.Gerakan ngoyod dilakukan dengan posisi tangan kanan ngagem dan tangan kiri lurus kesamping kiri, gerakan tangan dilakukan naik dan turun mengikuti tempo gamelan. Posisi badan ngaed atau mendak dengan kaki kanan napak sirang sejajar dengan ibu jari kaki kiri,gerakan kepala meliuk-liuk mengikuti gerakan tangan.

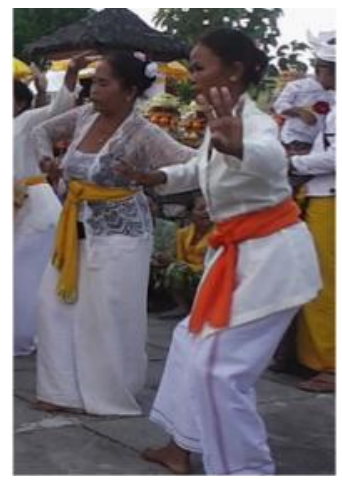

Gambar 2

Gerakan Ngoyod pada tari Reteng
Gerakan ketiga adalah mentang tangan, yaitu gerakan membentangkan kedua tangan ke samping kanan dan kiri. Gerakan mentang tangan pada tari Renteng dilakukan sebagai akhir dari komposisi keseluruhan gerak. Gerakan mentang tangan dapat dilihat pada gambar 3. Gerakan ini dilakukan dengan posisi kedua tangan memutar ke atas dan berakhir sejajar lurus ke samping kanan dan kiri. Badan berputar setengah lingkaran menghadap ke depan dengan posisi berdiri. Posisi kaki pada gerakan ini napak sirang dengan kaki kanan berada di depan sejajar dengan ibu jari kaki kiri.

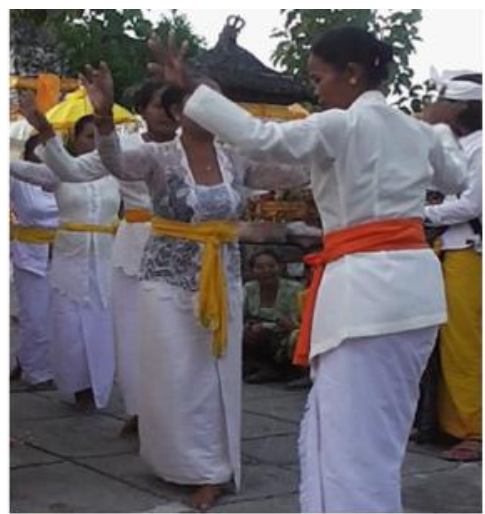

Gambar 3

Gerakan Mentang tangan pada tari Renteng

Ketiga gerakan pada tari Renteng merupakan gerakan sederhana yang tidak rumit, mudah dilakukan serta dapat dipahami. Gerak sederhana adalah gerakan yang tampaknya gampang untuk dilakukan. Gerakan yang sederhana itu bisa menjadi sangat baik jika dilakukan dengan tepat atau sempurna (I Wayan Dibia, FX. Widaryanto 2006). Gerakan-gerakan tersebut dapat dilakukan dengan teknik yang tidak begitu sulit, namun tepat dan sesuai seperti gerakan penari yang menguasai teknik dasar tari.

Unsur desain dalam seni tari terdiri dari desain lantai, yaitu garis pada lantai yang dilalui oleh penari. Dan desain atas, yaitu garis yang dibentuk oleh penari melalui ruang diatas lantai. Menurut Soedarsono, desain lantai atau floor design adalah garis-garis di lantai yang dilalui oleh penari, atau garis-garis di lantai yang di buat oleh formasi penari kelompok. Desain atas atau air design adalah desain di atas lantai yang dilihat oleh penonton, dan tampak terlukis pada ruang yang berada di atas lantai (Murgiyanto 1992). 


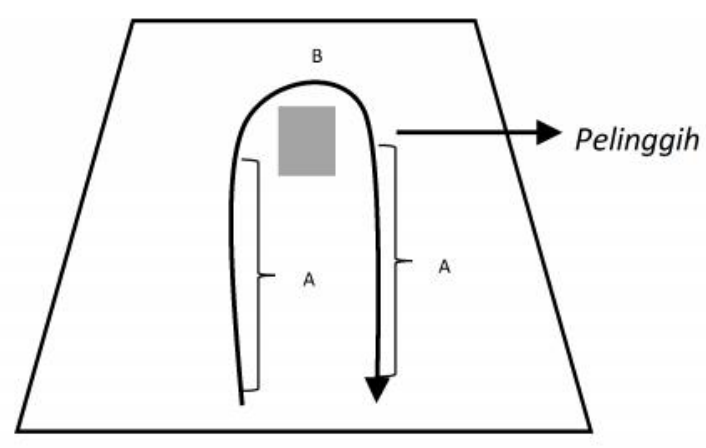

Gambar 4

Garis lurus (A) dan garis melengkung (B) yang terdapat pada desain lantai tari Renteng

Desain lantai yang dilalui oleh penari Renteng membentuk garis lurus dan melengkung, dapat dilihat pada gambar 4. Desain atas atau air design, seperti yang dijelaskan diatas merupakan garis yang terbentuk melalui penari dalam ruang yang ada pada lantai. Terbentuknya desain atas pada penari diakibatkan oleh garis-garis yang ditimbulkan oleh anggota badan penari itu sendiri, yang merupakan implementasi gerak tari dari penari. Pada tari Renteng, terdapat lima jenis desain atas yaitu bersudut, lurus, kontras, horisontal, dan datar dari ketiga jenis gerakan.

Unsur desain pada tari Renteng merupakan pengelompokan desain yang tidak terlalu banyak dan rumit sehingga motif-motif gerak dapat menimbulkan kesan artistik serta memberikan sentuhan emosional yang khas pada tari Renteng. Kesederhanaan desain pada tari Renteng tersusun secara terpadu membentuk tarian khas dan didominasi oleh beberapa desain seperti lurus, bersudut dan kontras. Elemen-elemen tersebut tersusun (direncanakan atau tidak) secara terpadu sehingga membentuk suatu tari atau koreografi yang khas. Dalam suatu koreografi, mungkin terlihat adanya dominasi dari satu elemen tertentu (I Wayan Dibia, FX. Widaryanto 2006).

Busana atau kostum tari adalah unsur penunjang dalam pertunjukan tari yang digunakan sebagai penutup tubuh penari, serta memberikan sebuah identitas pada tari tersebut. Dalam tari tradisi, busana tari atau kostum tari sering berupa pakaian adat atau pakaian khas daerah yang merupakan ciri khas tari yang bersangkutan (Murgiyanto 1992). Busana yang menempel pada tubuh penari merupakan cerminan identitas diri, baik tarinya maupun asal dari tari itu sendiri (Puspawati 2013). Dalam tari tradisional Bali yang bersifat ritual dan sakral, busana atau kostum yang digunakan dapat berupa kostum khusus pentas yang dapat memberikan keindahan ekspresi bagi yang memakainya maupun busana adat yang digunakan ketika pelaksanaan upacara keagamaan.

Busana atau kostum yang digunakan oleh para penari Renteng adalah busana adat, yaitu busana yang digunakan pada saat kegiatan adat maupun keagamaan. Busana adat tersebut merupakan busana yang dipergunakan dalam kegiatan keagamaan dan telah ditetapkan sebagai busana tari, yang terdiri dari kamben atau kain panjang berwarna putih, baju kebaya berwarna putih, dan sasenteng atau selendang berwarna putih maupun kuning. Contoh busana yang digunakan oleh penari renteng dapat dilihat pada gambar 1, 2, dan 3. Busana tersebut menjadi ciri khas dan identitas dari tari Renteng. Busana adat adalah busana yang digunakan dalam kegiatan adat sesuai dengan kebiasaan yang berlaku di kalangan masyarakat setempat, yang wajib digunakan dan sudah ditetapkan, baik dalam ritus yang bersifat profesional maupun yang ada di pura. Busana adat yang dipakai oleh penari sekaligus menjadi busana tari (I Wayan Dibia, FX. Widaryanto 2006).

Kesederhanaan busana pada tari Renteng dapat terlihat dari busana yang digunakan yaitu busana adat ke pura yang digunakan secara umum oleh masyarakat Bali. Busana adat yang digunakan oleh para penari Renteng tidak berlebihan dan sederhana, serta telah ditetapkan untuk digunakan dalam kegiatan keagamaan sekaligus menjadi busana tari tanpa adanya penambahan-penambahan yang dapat menimbulkan pusat perhatian secara berlebihan. Busana adat tersebut secara turun-temurun menjadi identitas yang dibanggakan oleh masyarakat desa Saren. Secara konseptual pakaian adat memberikan makna yang mengacu pada pakaian yang sudah dipakai secara turun-temurun yang merupakan salah satu identitas dan dapat dibanggakan oleh sebagian besar pendukung kebudayaan itu (Agung 2004).

Iringan musik merupaka salah satu elemen yang tidak dapat dipisahkan dalan pertunjukan tari. Melalui iringan musik, sebuah tarian akan memiliki nafas dan jiwa serta memberikan identitas pada tari tersebut. Pada tari Renteng, antara gerak tari dan gamelan yang mengiringi menimbulkan persenyawaan sehingga memberikan nafas dan jiwa pada tarian ini serta memberikan sebuah identitas kesederhanaan melalui kesatuan gerak, iringan musik dan notasi gending yang sederhana. dalam penyajiannya, antara tarian dan iringan musik pada tari Renteng saling mendominasi. Ada tarian yang memperlihatkan keberimbangan interaksi, dimana musik dan tari secara bergantian saling mengikat; dan ada pula tarian yang dominan sehingga musik yang mengikuti, atau 


\section{GELAR Jurnal Seni Budaya}

musik hanya sebagai ilustrasi dari tariannya (I Wayan Dibia, FX. Widaryanto 2006). Karena tari Renteng tidak memiliki struktur tari pada umumnya, penyesuaian gerak dengan iringan musik atau gamelan dilakukan dengan tempat atau panggung dimana penari Renteng menari. Jika penari Renteng memulai tariannya di halaman luar dan tengah pura maka iringan musik menyesuaikan dengan tarian. Namun, jika tarian telah sampai di halaman utama pura, maka penarilah yang menyesuaikan dengan iringan musik.

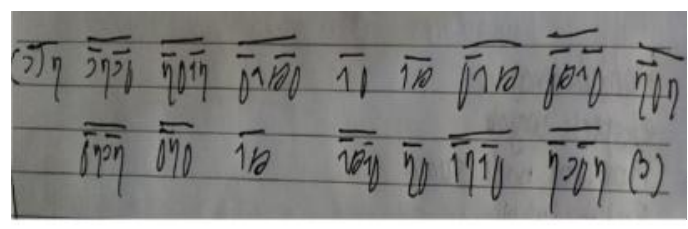

Gambar 5

Notasi gending Bebonangan pada tari Renteng.

Iringan musik atau gamelan yang mengiringi tari Renteng dapat dikatakan sederhana, hanya diiringi oleh beberapa instrumen gamelan Balaganjur. Jenis instrumen yang digunakan untuk mengiringi tari Renteng adalah trompong, kajar, gong, ceng-ceng, dan kendang dengan gending yang dimainkan yaitu gending Bebonangan. Jenis instrumen pada tari Renteng tersebut dapat dikatakan sebagai gamelan Bebonangan, dilihat dari struktur gending yang dimainkan, hal tersebut terlihat dari permainan trompong yang mendominasi melodi. Contoh notasi geding Bebonangan yang mengiringi tari Renteng dapat dilihat pada gambar 5. Bebonanganatau Bonang, atau dalam karawitan Jawa disebut Bonangan adalah intrumen pencon yang ukurannya lebih kecil dari gong. Sementara lagu yang dihasilkan oleh gamelan Bebonangan juga disebut gending Bebonangan yang oleh masyarakat Bali lebih dikenal dengan gending Balaganjur dan atau Kalaganjur (Yasa 2018). Bandem mengatakan bahwa Bonang atau Bebonangan adalah sebuah barungan gamelan yang terdiri dari berbagai instrumen pukul atau percussive yang memakai pencon seperti reong, trompong, kajar, kempli, kempur, dan gong dengan memakai dua buah kendang yang dimainkan memakai pukulan cedugan (Janardhana 2012).

Konsep kesederhanaan unsur pada tari Renteng tergambarkan melalui pertama, gerak sebagai substansi utama dan merupakan ekspresi bahasa nonverbal yang meliputi gerak ngelikas, ngoyod, dan mentang tangan. Gerakan-gerakan tersebut dapat dilakukan dengan teknik yang tidak begitu sulit, namun tepat dan sesuai seperti gerakan yang penari yang menguasai teknik dasar tari. Ketiga gerakan pada tari Renteng merupakan gerakan sederhana yang tidak rumit, mudah dilakukan serta dapat dipahami. Kedua, desain yaitu garis-garis yang memberikan bentuk pada gerak maupun lintasan penari meliputi desan lantai (floor design) lurus dan melengkung. Desain atas (air design atau upper design) terdiri dari lurus, bersudut, kontras, horisontal, dan datar. Kesederhanaan desain pada tari Renteng dapat dikatakan sebagai kesederhanaan estetik yang tersusun secara terpadu membentuk tarian khas dan didominasi oleh beberapa desain.

Ketiga, busana yang digunakan oleh penari adalah busana adat ke pura. Busana tersebut didominasi oleh warna putih yang memberikan identitas pada tari Renteng. Busana yang digunakan tidak berlebihan dan sederhana, artinya kesederhanaan busana pada tari Renteng adalah busana yang telah ditetapkan untuk digunakan dalam kegiatan keagamaan tanpa adanya penambahanpenambahan yang dapat menimbulkan pusat perhatian secara berlebihan. Keempat, gamelan yang mengiringi tari Renteng adalah gamelan Bebonangan, yaitu jenis instrumen pencon seperti reong, trompong, kajar, gong, dan ditambah kendang serta ceng-ceng dengan gending yang dimainkan adalah gending Bebonangan. Antara gamelan dan tarian pada tari Renteng saling mendominasi serta memberikan identitas kesederhanaan melalui kesatuan gerak dan iringan musik. Kesederhanaan iringan musik pada tari Renteng berdasarkan bentuk iringannya adalah sebagian besar didominasi oleh instrumen pencon, yang dapat dimainkan oleh masyarakat umum.

\section{Kesederhanaan Struktur}

Struktur merupakan suatu susunan yang membentuk satu rangkaian atau pola, dapat juga diartikan sebagai pengaturan unsur suatu benda. Struktur atau susunan mengacu pada bagaimana unsur dasar masing-masing kesenian tersusun hingga berwujud (Djelantik 2008). Struktur dalam tari adalah hubungan antara bagian-bagian tari secara keseluruhan (Suandewi 2016). Struktur tari Renteng di desa Saren dalam kajian ini, dilihat dari susunan yang membentuk tarian seperti struktur gerak dan penyajiannya. Struktur gerak yang dimaksud adalah susunan dari ketiga jenis gerak yang terdapat pada tari Renteng yang membentuk suatu rangkaian atau pola gerak. Sedangkan struktur penyajian adalah susunan pementasan atau dapat diartikan sebagai tahapan pementasan tari Renteng. 
Susunan gerak tari Renteng dapat diajabarkan sebagai berikut pertama, ngelikas yang dilakukan dengan Susunan gerak tari Renteng dapat diajabarkan sebagai berikut pertama, ngelikas yang dilakukan dengan posisi badan mendak atau ngaad menghadap ke samping kanan, sedangkan arah pandang ke depan. Gerakan berjalan dilakukan dengan posisi kaki saling menyilang secara bergantian. Dilanjutkan dengan gerakan ngoyod dilakukan dengan posisi badan ngaad dan posisi tangan ngembat. Posisi kaki tapak sirang pada dan badan direbahkan ke kanan dan kiri mengikuti tempo gamelan serta ayunan tangan mengikuti rebahan badan. Dan terakhir adalah mentang tangan dilakukan dengan posisi kaki tapak sirang pada dan badan berdiri menghadap ke depan, kedua tangan memutar masing-masing seperempat putaran di atas kepala dan berakhir di samping kanan maupun kiri dengan posisi lurus. Gerakan ini dilakukan dengan sangat sederhana tanpa ada kompleksitas, hanya memutar kedua tangan keluar dan berakhir dengan kedua tangan lurus ke samping. Struktur gerak tari Renteng merupakan susunan dari rangkaian gerak tari Renteng yang membentuk satu pola gerakan, dengan hitungan keseluruhan adalah $3 \times 8$ hitungan. Pola gerakan tersebut dilakukan atau ditarikan secara berulang-ulang dari awal mulai sampai berakhirnya tarian. Ketiga gerakan tersebut bersifat repetitif yaitu gerakan yang sama dan diulang terus menerus. Secara umum repetitif merupakan sebuah kata sifat yang berarti pengulangan atau bersifat pengulangan (Kurniadi 2019).

Struktur penyajian tari Renteng memiliki dua tahapan yaitu pertama, mendak renteng yang dilakukah di halaman luar pura atau jaba sisi; kedua, ngerenteng yaitu melakukan atau menarikan tari Renteng dari candi bentar atau pintu masuk menuju ke halaman tengah pura atau jaba tengah dan halaman utama pura atau jeroan pura melalui kori agung atau pintu utama menuju halaman utama pura. Di halaman utama pura, penari menuju ke salah satu pelinggih yang berada ditengah-tengah halaman, serta mengitari pelinggih tersebut searah dengan jarum jam (murwa daksina) dan kembali ke halaman tengah dan halaman luar pura melalui kori agung sebagai tanda berakhirnya tarian. Hal tersebut merupakan susunan yang membentuk pola atau rangkaian yang sederhana. Kesederhanaan tersebut terlihat dari susunan pola gerak yang sama dan diulang-ulang, dan susunan penyajian atau pementasan tari Renteng yang tidak kompleks. Konsep kesederhanaan struktur pada tari Renteng merupakan rancangan ide atau gagasan yang tercapai melalui penerapan susunan gerak dan penyajian yang sederhana, dan ditarikan secara berulang-ulang.

\section{Kesederhanaan Teknik}

Teknik adalah cara untuk melakukan sesuatu baik secara fisik maupun mental. Teknik dapat diartikan sebagai suatu cara untuk melakukan sesuatu melalui proses baik fisik maupun mental. Pada tari, teknik lebih mengarah pada gerak atau teknik tari yaitu suatu cara yang dilakukan oleh tubuh melakukan tarian(I Wayan Dibia, FX. Widaryanto 2006). Dalam tari Renteng sendiri, secara spesifik tidak dituntut adanya teknik tari seperti pada tari-tarian lainnya yang ada di Bali daratan. I Ketut Suara mengatakan bahwa, tarian ini ditarikan secara langsung saat itu juga. Tidak ada suatu persiapan seperti latihan-latihan, dan tidak ada keharusan menguasai teknik tari.

Tari Renteng dilakukan dengan teknik yang tidak memiliki kerumitan. Bukan berarti tarian ini tidak memiliki teknik tari seperti pada tarian lainnya, akan tetapi jika dianalisis secara mendalam terdapat pakem-pakem atau kaidah-kaidah dasar tari Bali. Ni Made Sedit selaku penari Renteng yang masih aktif sampai saat ini, mengatakan bahwa terdapat cara atau sikap yang harus dikuasai oleh para penari Renteng yaitu sikap badan, tangan, dan kaki. Ditambahkan pula, ketika merendahkan badan, sikap dan posisi kaki dan tangan para penari harus sesuai dengan pakem yang terdapat pada tari Renteng. Berdasarkan pendapat tersebut, teknik yang terdapat pada tari Renteng menitik beratkan pada teknik agem, ngaad, serta tandang.

Teknik agem pada tari Renteng dilakukan dengan posisi rendah atau ngaad, posisi tangan kanan ditekuk dan telapak tangan menghadap ke samping kanan sehingga ibu jari tangan kanan hampir menempel di dada sedangkan tangan kiri lurus ke samping kiri. Ngaad pada tari Renteng dilakukan dengan merendahkan posisi badan, kedua kaki ditekuk dan telapak kaki tapak sirang pada. Teknik tandang atau cara berjalan, pada tari Renteng terdapat dua jenis gerakan berjalan yang dilakukan oleh penari Renteng yaitu gerakan berjalan menyilangkan kaki secara bergantian, dan gerakan berjalan menyilang dengan langkah kaki tetap.

Secara keseluruhan dari ketiga gerakan yang terdapat pada tari Renteng, dilakukan sesuai dengan pakem atau teknik dasar tari Bali pada umumnya. Namun, karena para penari Renteng tidak pernah mendapatkan pelatihan atau mempelajari teknik dasar tari secara khusus, maka gerakan-gerakan pada tari Renteng terlihat sederhana. Jika dilihat secara 


\section{GELAR Jurnal Seni Budaya}

mendalam, gerakan tari Renteng yang nampak sederhana tersebut dilakukan dengan baik dan tepat sesuai dengan teknik dasar tari Bali. Gerak sederhana adalah gerakan yang tampaknya gampang untuk dilakukan. Gerakan yang sederhana itu bisa menjadi sangat baik jika dilakukan dengan tepat atau sempurna (I Wayan Dibia, FX. Widaryanto 2006). Kesederhanaan teknik pada tari Renteng dapat dikatakan sebagai suatu cara yang dilakukan oleh para penari dalam menarikan tari Renteng melalui proses yang gampang untuk dilakukan. Konsep kesederhanaan teknik pada tari Renteng merupakan entitas yang dilakukan dengan sederhana. Setiap penari Renteng, dalam menarikan tarian ini dilakukan dengan cara yang gampang atau tingkat kompleksitasnya rendah dalam artian tidak rumit.

\section{Kesimpulan}

Konsep kesederhanaan unsur atau elemen pada tari Renteng di Desa Saren, Nusa Penida, Klungkung merupakan kesederhanaan komposisi dari unsur-unsur yang terdapat pada tarian ini. Konsep kesederhanaan unsur tersebut tergambarkan melalui pertama, gerak sebagai substansi utama dan merupakan ekspresi bahasa nonverbal yang meliputi gerak ngelikas, ngoyod, dan mentang tangan; kedua, desain yaitu garis-garis yang memberikan bentuk pada gerak maupun lintasan penari meliputi desan lantai (floor design) lurus dan melengkung; desain atas (air design atau upper design)terdiri dari lurus, bersudut, kontras, horisontal, dan datar; ketiga, busana yang digunakan oleh penari adalah busana adat ke pura. Busana tersebut didominasi oleh warna putih yang memberikan identitas pada tari Renteng. Busana yang digunakan tidak berlebihan dan sederhana, artinya penggunaan busana pada tari Renteng adalah busana yang telah ditetapkan untuk digunakan dalam kegiatan keagamaan tanpa adanya penambahan-penambahan yang dapat menimbulkan pusat perhatian secara berlebihan; keempat, gamelan yang mengiringi tari Renteng adalah gamelan Bebonangan, yaitu jenis instrumen pencon seperti reong, trompong, kajar, gong, dan ditambah kendang serta ceng-ceng dengan gending yang dimainkan adalah gending Bebonangan. Antara gamelan dan tarian pada tari Renteng saling mendominasi serta memberikan identitas kesederhanaan melalui kesatuan gerak dan iringan musik. Kesederhanaan iringan musik pada tari Renteng berdasarkan bentuk iringannya adalah sebagian besar didominasi oleh instrumen pencon, yang dapat dimainkan oleh masyarakat umum.
Susunan gerak tari Renteng memiliki struktur pola repetitif yang artinya rangkaian gerak yang sama dan ditarikan secara terus menerus dan berulang-ulang sampai akhir tarian. Pada pementasan tari Renteng, struktur penyajiannya sangat sederhana dan tidak memiliki tingkat kompleksitas yang sulit. Konsep kesederhanaan struktur pada tari Renteng merupakan rancangan ide atau gagasan yang tercapai melalui penerapan susunan gerak dan penyajian yang sederhana, dan ditarikan secara berulang-ulang.

Teknik tari Renteng tidak dilakukan melalui proses yang rumit. Artinya teknik pada tari Renteng adalah suatu cara yang dilakukan oleh para penari dalam menarikan tari Renteng melalui proses yang gampang untuk dilakukan. Konsep kesederhanaan teknik pada tari Renteng merupakan entitas yang dilakukan dengan sederhana oleh setiap penari Renteng,melaluicara yang gampang atau tingkat kompleksitasnya rendah dalam artian tidak rumit.

\section{KEPUSTAKAAN}

Agung, A. A. Ayu Ketut. 2004. Busana Adat Bali. Edisi dipe. Denpasar: Pustaka Bali Post.

Dharsono. 2017. Seni Rupa Modern. Bandung: Rekayasa Sains.

Djayus, Nyoman. 1980. Teori Tari Bali. Denpasar: Sumber Mas Bali.

Djelantik, A. A. M. 2008. Estetika Sebuah Pengantar. Jakarta: Masyarakat Seni Pertunjukan Indonesia.

Elkin, Bruce. 2004. Kesederhanaan Dan Kesuksesan: Membangun Hidup Yang Anda Dambakan. Yogyakarta: Pustaka Pelajar.

Hadi, Y. Sumandiyo. 2007. Kajian Teks Dan Konteks. Cetekan pe. Yogyakarta: Pustaka Book Publisher.

Hawkins, Alma M. 2003. Mencipta Lewat Tari. Yogyakarta: Manthili Yogyakarta.

I Wayan Dibia, FX. Widaryanto, Endo Suanda. 2006. Tari Komunal. Edisi Uji. Jakarta: Lembaga Pendidikan Seni Nusantara.

Ibeng, Parta. 2019. "Pengertian Konsep, Fungsi, Ciri, Unsur, Beserta Karakteristik." http:// pendidikan.co.id. 
Janardhana, Kumara. 2012. "Balaganjur Dan Perkembangannya." http://blog.isidps.ac.id.

Kurniadi, Moch. Rizky Prasetya. 2019. "Arti Repetitif." http://lektur.id.

Langer, Suzanne K. 2006. Problematika Sini. Bandung: Sunan Ambu Perss.

Maharsi. 2009. Kamus Jawa Kawi Indonesia. Cetakan Pe. Yogyakarta: Pura Pustaka.

Murgiyanto, Sal. 1992. Koreografi. Jakarta: Pusat Pembukuan Departemen Pendidikan dan Kebudayaan.

Penyusun, Tim. 2000. Pendokumentasian GerakGerak Tari Bali. Denpasar: Kantor Dokumentasi Budaya Bali Provinsi Bali.

Puspawati, Gusti Ayu Made. 2013. Tata Rias Dan Busana. Cetakan Pe. Malang: Wineka Media.

Rihandiyo, R. 2010. "Kajian Teori Dan Operasionalisasi Konsep." http://eprints.undip.ac.id.

Soedarsono. 1981. Tari-Tarian Indonesia I. Jakarta: Proyek Pengembangan Media Kebudayaan
Direktorat Jendral Kebudayaan Departemen Pendidikan dan Kebudayaan.

Suandewi, Gusti Ayu Ketut. 2016. "Tari Rejang Wastra Di Desa Demulih Kabupaten Bangli Kajian Bentuk Dan Fungsi." Kalangwan 2: 94-99.

Yasa, I Ketut. 2018. Seni Dan Agama. Tabanan: Pustaka Ekspresi.

\section{Narasumber:}

1. Jero Mangku Gede Ngurah (47th), petani, pemangku, wawancara pada tanggal 28 Februari 2019 di rumahnya, dusun Saren I, Desa Adat Saren, Batumadeg, Nusa Penida, Klungkung.

2. I Ketut Suara (45th), karyawan swasta, mantan kelian adat periode 2016-2019, wawancara pada tanggal 28 Februari 2019 dirumahnya, dusun Saren I, desa adat Saren, Batumadeg, Nusa Penida, Klungkung.

3. Ni Made Sedit (50th), petani, penari Renteng, wawancara pada tanggal 25 Februari 2020 di Pura Geria Keniten, dusun Saren I, desa adat Saren, Batumadeg, Nusa Penida, Klungkung. 